\title{
The Effect of Citizens' Trust on their E-Participation: Moderating Role of Their Belief in Power Distance and Perceived Risk and Mediating Role of Their Ambiguity Acceptance and Attitudes
}

Farajollah Rahnavard ${ }^{1}$ Associate Professor. in Public Administration, Institute for Management and Planning Studies (IMPS), Tehran, Iran. (corresponding Author).

Maryam Hosseini2 ${ }^{2}$ M.A. in Public Administration, Institute for Management and Planning Studies (IMPS), Tehran, Iran.

\begin{abstract}
With the advancement of information and communication technologies in the present world, organizations in both public and non-public sectors have embarked on developing e-participation in the relationships between service organizations and main stakeholders. The purpose of this study is to determine the impact of citizens' trust in e-participation with regard to the moderating roles of perceived risk and belief in power distance, and mediating roles of citizens' attitudes and ambiguity acceptance. It was an applied research and survey method was used to collect data. The recipients of Tehran Municipality services comprised the statistical population. In path analysis the sample size is determined on the basis of the number of structural indicators and the level of significance. Accordingly, the sample size of 364 was applied using Cohen's table. The results indicate that e-participation is at a moderate level. Research findings suggest that citizens' confidence in e-participation is positive and ambiguity in the relationship between these two variables appears as a mediator with a positive impact on e-participation. Meanwhile, the findings indicate that e-participation is not affected by citizens'attitudes and that beliefin power distance moderates the relationship between citizens' trust and e-participation.However, the perceived risk variable does not play a role as a moderator in the relationship between citizen's attitudes and e-participation.
\end{abstract}

Keywords: E-Participation, Citizens' Trust, Citizens' Attitude, Perceived Risk, Individual Belief.

1. frahnavard@imps.ac.ir 


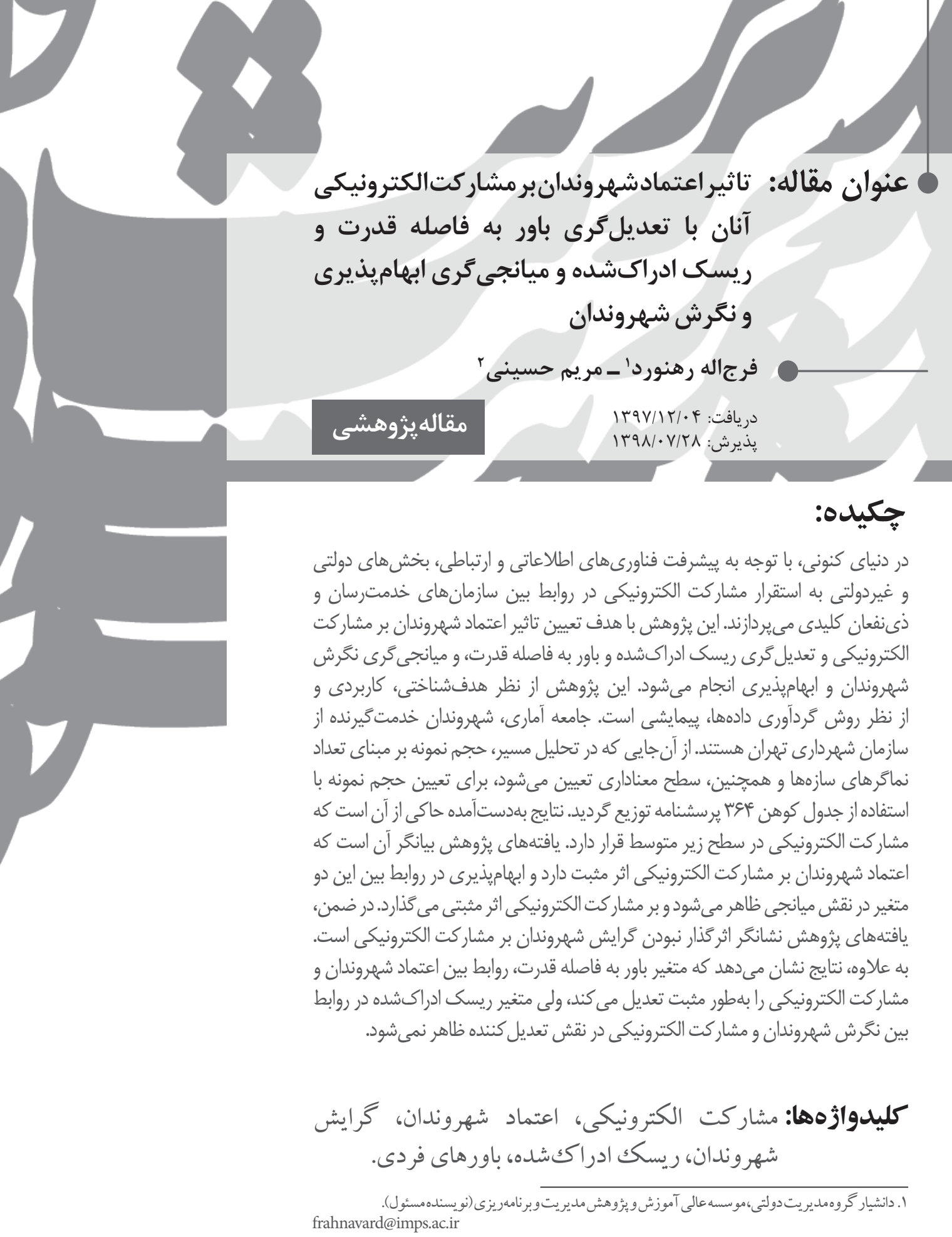
frahnavard@imps.ac.ir

r. دانش آموخته كارشناسى ارشدمديريت دولتى، موسسه عالى آموزش و بثروش مديريت و برنامهريزى. 


\section{مقدمه}

مشاركت شهروندان يكى از يايههاى اصلى مردمسالارى محسوب مىشود و استقرار جنين نظامى به مفهوم افزايش نقش شهروندان در اداره امور عمومى است. مشاركت از الزامهاى زندكى مركى شهرى است و هنكامى تحقق مىيابد كه شهرنشينان از حالت زندكى فردى درآيند و با احساس مسئوليت جمعى به شهروندان بدل شوند (Irvin \& Stansbury, 2004). مطابق نظريه الارزش

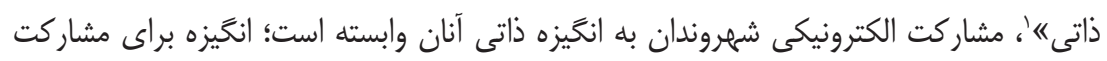

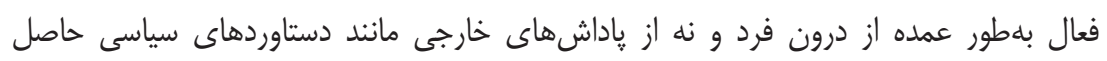

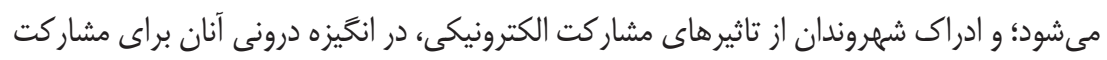
در فرايند تصميمگيرى سياسى اثر گذار است (Lee \& Kim, 2012). مشاركت الكترونيكى جيز جديدى نيست، و با گسترش اينترنت مسير تكاملى خود را طى مى كند و سازوكارهاى نوينى رابكار بـار مى گيرد (Sæbø et al., 2008). به عبارت ديخر، ظهور مشاركت الكترونيكى به عنوان يكى فرايند كه قادر به ايجاد و حمايت از ابتكارهاى مردمسالارانه است، به تكامل بسيارى از خدمات ارتباطى در رشد سريع و يذيرش اينترنت وابسته است (Sanford \& Rose, 2008). به هر حال، در دنياى كنونى با توجه به ييشرفت فناورىهاى اطلاعاتى و ارتباطى، مشاركت الكترونيكى نه يك گزينه بلكه يك ضرورت راهبردى براى سازمانهاى عمومى است. هرجند يزوهش در خصوص مشاركت الكترونيكى در كشورهاى مختلف شروع شده است

(Scherer \& Wimmer, 2014; Alharbi \& Kang, 2014; Alharbi et al., 2016) گستره آن با در نظرگرفتن فرهنَّاى مختلف در حدى نيست كه بتوان به حكم كلى و فراگير در

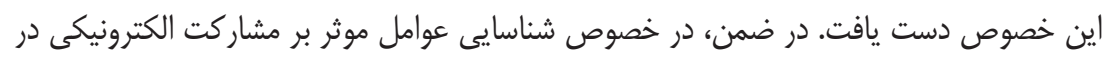

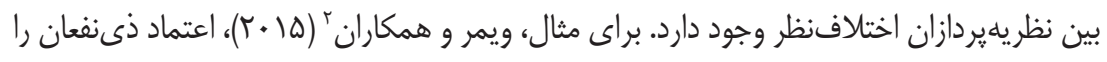

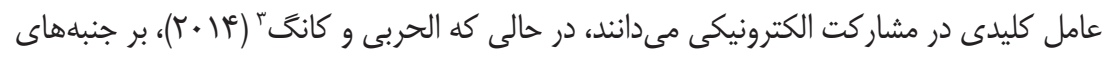

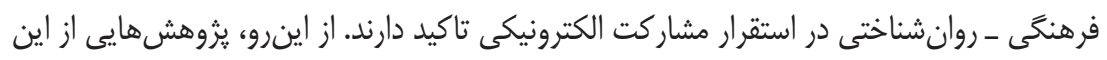
دست ميتواند در رفع يا تقليل اختلافنظر انديشمندان اثركذار باشد. ريسك ادراكى از ييشينههاى

1. Intrinsic Value

2. Wimmer et al.

3. Alharbi \& Kang 
رايج در تشريح رفتار است (Andrews \& Boyle, 2008). يذيرش افراد براى مشاركت

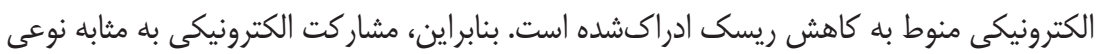

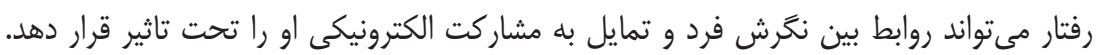

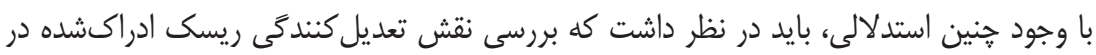

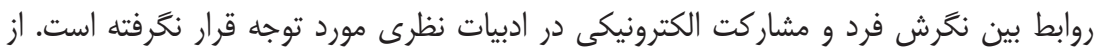
اينرو، نتايج اين يزوهش در ترميم هنين شكاف يزوهشى نيز قابلتوجه است. به عالاوه، نقش دران

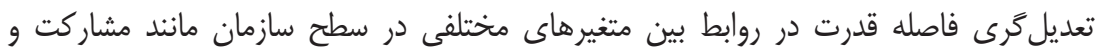

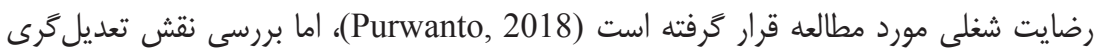

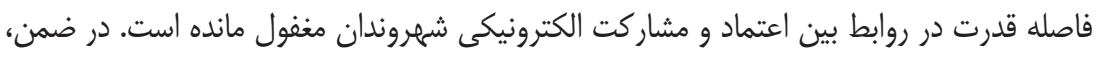
نتايج اين يثوهش در ارتقاى دانش اقليمكرا با ارائه مدل بومى مشاركت الكترونيكى اثر كذار است.

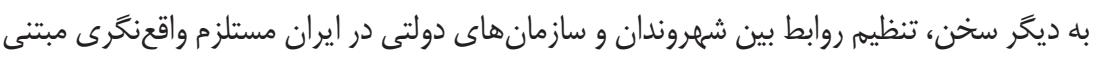
بر يافتهاى يثوهشى است كه نتايج اين يخوهش مى تونواند در اين مسير راهخشا باشد.

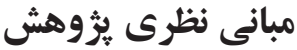

اكر دولت الكترونيك را به كاربرد فناورى اطلاعاتى و ارتباطى در ارائه خدمات به شهروندان تعريف

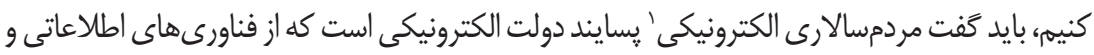

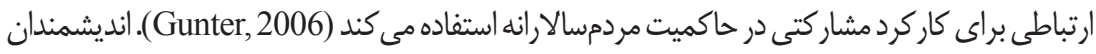
مردمسالارى الكترونيكى (Sæbø et al., 2011; Coleman, 2005)، عناصر كليدى در راهاندازى

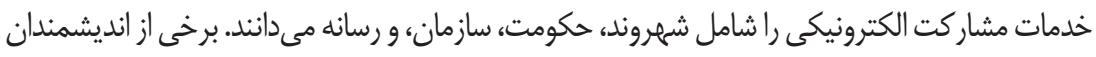

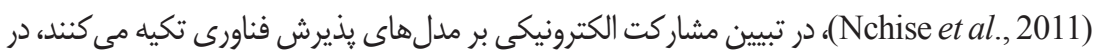

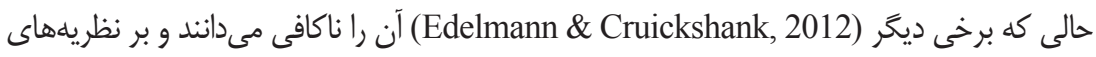

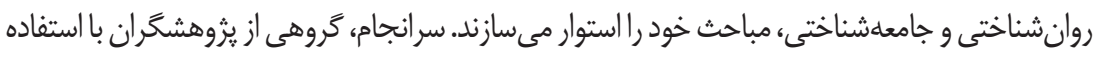

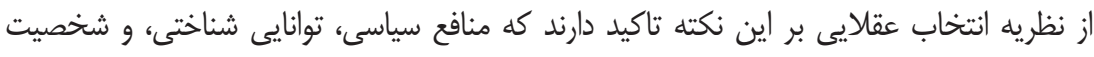
شهروندان، قصد مشاركت الكترونيكى آنان را تبيين مى كند (Denny \& Doyle, 2008). 


\section{مفهوم مشار كت الكترونيكى}

مشاركت الكترونيكى يكى از مفاهيم جديدى است كه در بي كسترش فناورىهاى اطلاعاتى و ارتباطى مطرح شده است و مراد از آن برقرارى رابطه الكترونيكى بين سازمانها و ذهى نفعان آنسان آست.

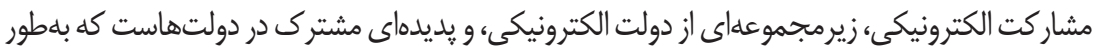
جدى استفاده از فناورى اطلاعات و ارتباطات (ICT)' را براى تقويت روابط دولت ـ شهروندان مدنظر

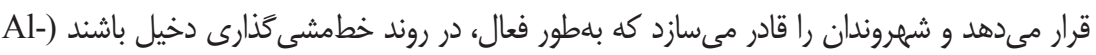

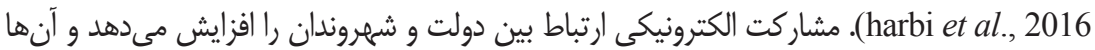

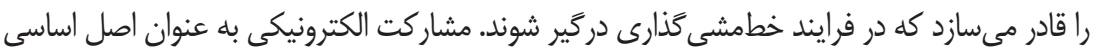

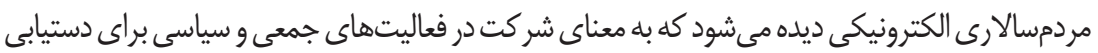
به اهداف مشترك است (Al-Dalou \& Abu-Shanab, 2013). برخى از انديشمندان با تاكيد بر نقش مشاركت الكترونيكى در تعميق مردمسالارى آن را تعريف مى كنند. فرض بر اين است كه مشاركت آنت

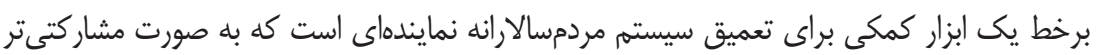

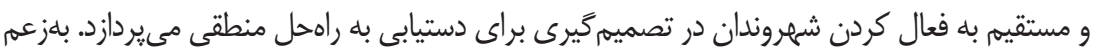

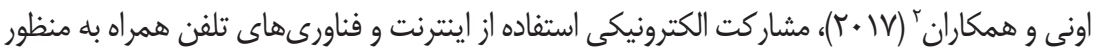

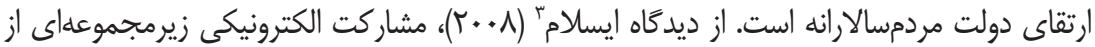

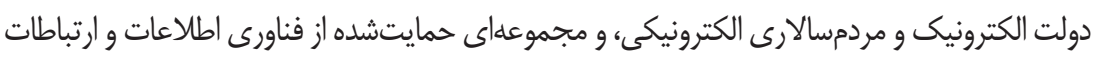
به منظور تسهيل مشاركت در دولت و حكومت است. ديخر تعاريف ارائهشده در خصوص مشاركت

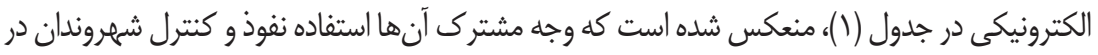
فرايندهاى تصميم كيرى دولتى با استفاده از فناورىهاى اطلاعاتى و ارتباطى است.

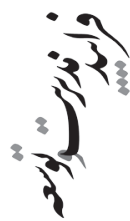

جدول 1: تعريف مشار كت الكترونيكى از ديدكاه انديشمندان

\begin{tabular}{|c|c|}
\hline تعريف & منبع \\
\hline 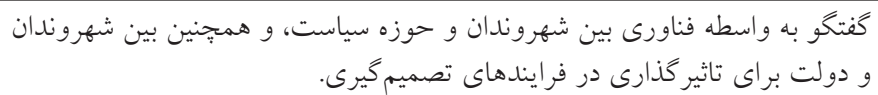 & $\begin{array}{l}\text { سابو و همكاران } \\
(\uparrow \cdot r \cdot r)\end{array}$ \\
\hline 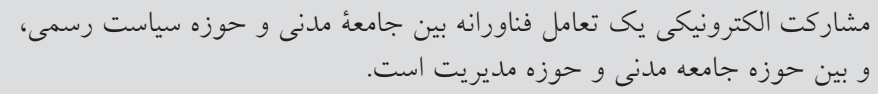 & توندجانخسارى" \\
\hline
\end{tabular}

1. Information and Communication Technology (ICT)

2. Oni et al.

3. Islam

4. Tundjungsari 
ادامه جدول 1: تعريف مشار كت الكترونيكى از ديد

\begin{tabular}{|c|c|}
\hline تعريف & منبع \\
\hline 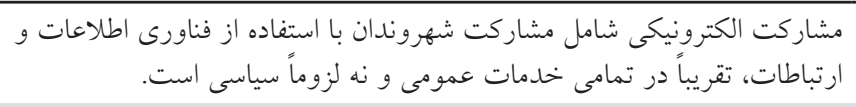 & 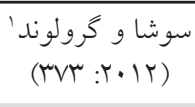 \\
\hline فرايند و توسعه رونتد سياسى استى استفاده از فناورىهاى رايانهاى و شبكهاى براى حمايت از & 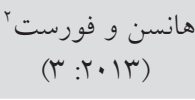 \\
\hline 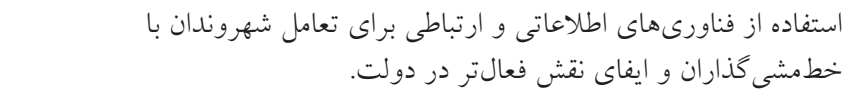 & 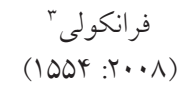 \\
\hline 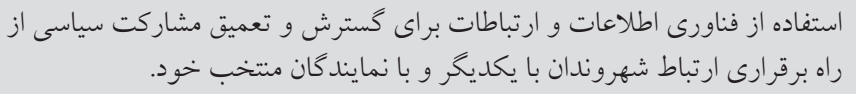 & 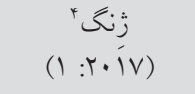 \\
\hline دخالت شهروندان در فرايند تصميم گيرى عمومى از راه اينترنت. & $\begin{array}{l}\text { داموراسكى } \\
(r \cdot Y \cdot(r)\end{array}$ \\
\hline مشاركت افراد و اشخاص از حقوقى در فرايند تصميم گيرى سياسى و ادارى با & 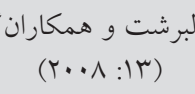 \\
\hline
\end{tabular}

عوامل موثر بر مشار كت الكترونيكى

يزوهشهاى قابلتوجهى در خصوص شناسايى متغيرهاى اثر گذار بر مشاركت الكترونيكى صورت

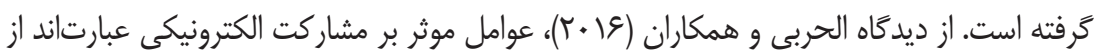

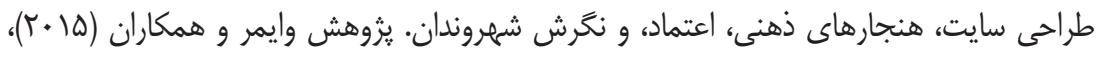
نشانخر اثر گذارى اعتماد سياسى، اعتماد اجتماعى، اعتماد فناورانه، اعتماد اخلاقى، و اعتماد اقتصادى لئى

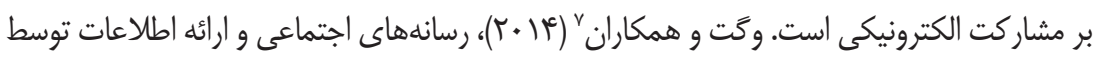

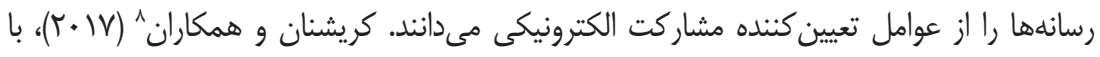

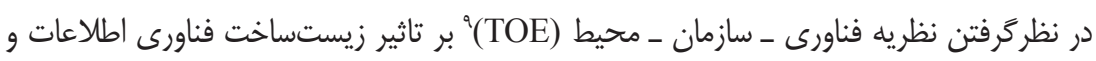
ارتباطات (زمينه فناورانه)، حاكميت (زمينه سازمانى)، و سرمايه انسانى (زمينه محيطى) بر مشاركت

1. Susha \& Grönlund

2. Hansson \& Fürst

3. Francoli

4. Zheng

5. Damurski

6. Albrecht et al.

7. Vogt et al.

8. Krishnan et al.

9. Technology-Organization-Environment (TOE) 
الكترونيكى تاكيد مى كنند. ديخر ثروهشها نيز با هدف شناسايى عوامل موثر بر ارتقاى مشاركت

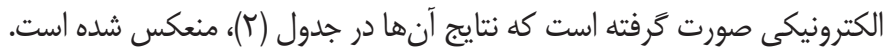

جدول r: عوامل موثر بر قصد مشاركت الكترونيكى شهروندان

\begin{tabular}{|c|c|}
\hline 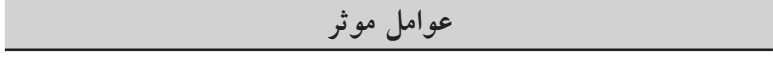 & منبع \\
\hline 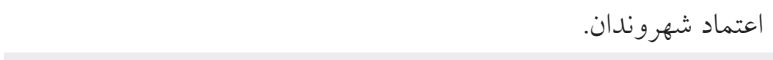 & 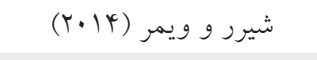 \\
\hline 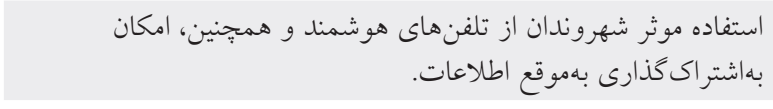 & 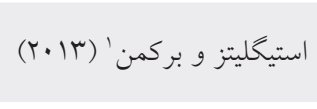 \\
\hline منابع، تعامل روانشناختى با سياست، نخرش، و هنجارهاى ذهنى. & اونى و همكاران (Y.IV) \\
\hline ذاطلاعاتى، ويز مدىى خواى جمعيتى. روانشناختى، اعتماد به دولت، كانالهاى & نام $\left.{ }^{r}\right)$ \\
\hline نخرش، اعتماد، طر احى وبسايت، و فرهنخ. & 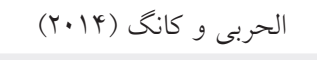 \\
\hline شر ايط نهادى و فناورانه. & 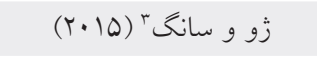 \\
\hline خدمات در دولت خدمات و فناورى اطلاعات و ادراك شهروندان از كيفيت & 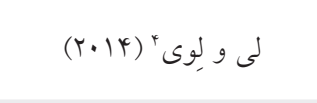 \\
\hline شكل حكومت، ساختارهاى دولتى، شر ايط مختلف قانونى و اجتماعى. & 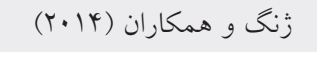 \\
\hline حاكميت اثربخش دولتى، خطمشى توسعه و توزيع ICT. & ويليامز و همكارانه (r|r. (Y) \\
\hline \multicolumn{2}{|l|}{ 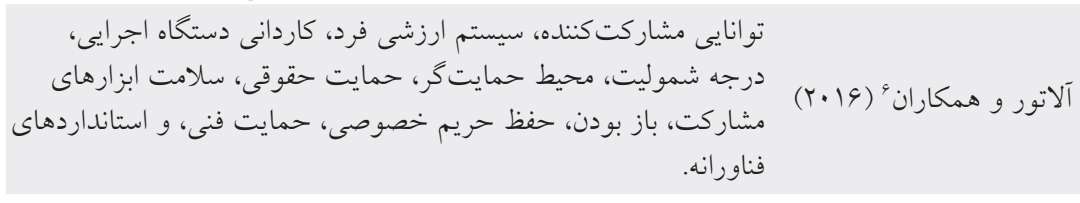 } \\
\hline غناى رسانه و اثرهاى اجتماعى آن. & 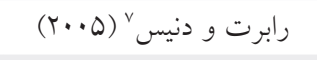 \\
\hline 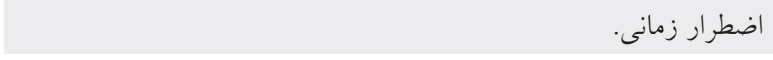 & 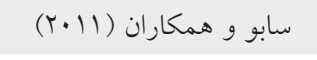 \\
\hline تمايل و توانايى مشاركت شهروندان. & هولخرسون و كارلسون^(Y) (Y. (Y) \\
\hline 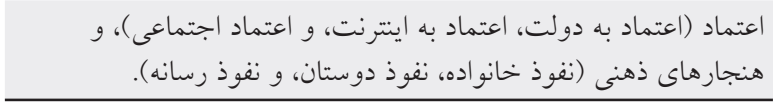 & و و همكاران (Y.19) \\
\hline
\end{tabular}

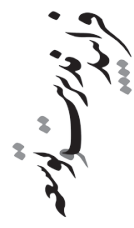

1. Stieglitz \& Brockmann

2. Nam

3. Jho \& Song

4. Lee \& Levy

5. Williams et al.

6. Alathur et al.

7. Robert \& Dennis

8. Holgersson \& Karlsson 
مل مل مفهومى بزوهش

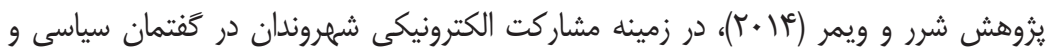
تصميه گيرىهاى مردمسالارانه موجب شده است كه نظر يثوهشگًران به حوزه مشاركت الكترونيكى بيشتر جلب شود. براى مثال، نتايج الحربى و همكاران (عا +r)، نشان مىدهد كه اعتماد و هنجارهاى ذهنى نقش مهمى در استقرار سازوكارهاى مشاركت الكترونيكى بين شهروندان و دولت ايفا مى كنند. جدول (r)، نشانگر تاثير گذارى عوامل در سطوح مختلف فردى، سازمانى، و دولتى بر مشار كت الكترونيكى شهروندان است. در اين يثروهش، تنها بر عوامل كليدى در سطح فردى تاكيد مى شود و مدل مفهومى به شرح شكل ( ()، بهدست مى آيد. بايد در نظر داشت كه مدل طراحى شده يك مدل تلفيقى است كه در آن برخى از متغيرهاى ميانجى و تعديل كننده بر مبناى استدلال عقلى مبتنى بر نظريه اقتضايى لحاظ شدهاند.

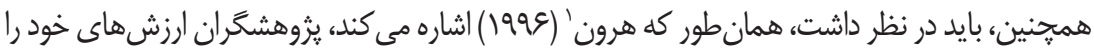

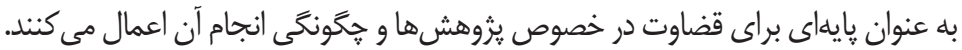

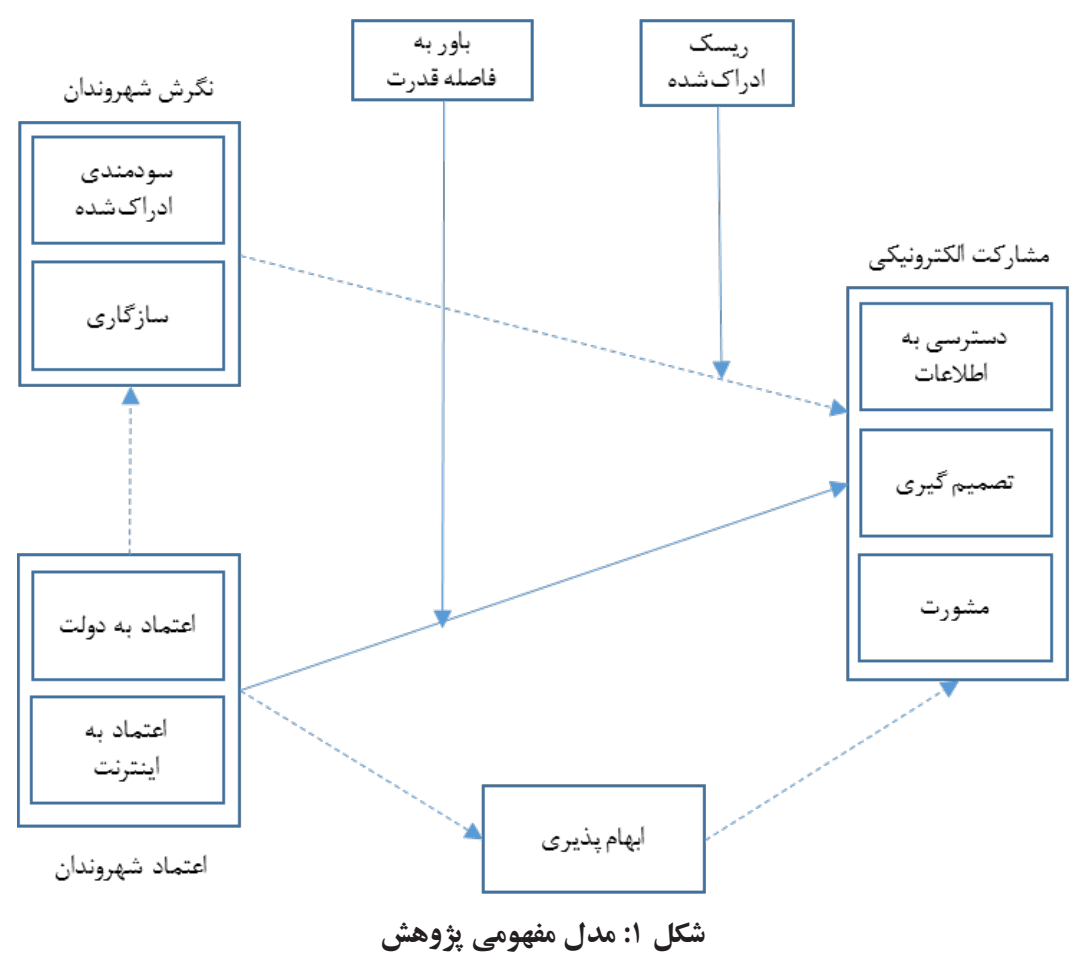

1. Heron 
با توجه به مدل مفهومى يزوهش، يرسش هاى زير قابل طرح هستند:

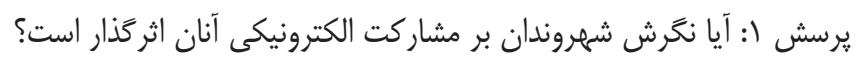

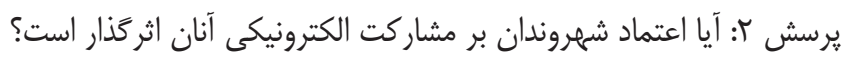

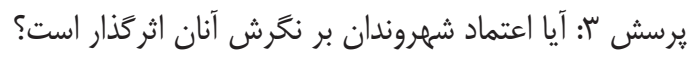

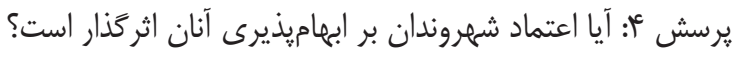

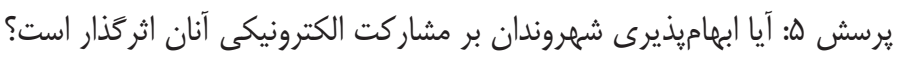

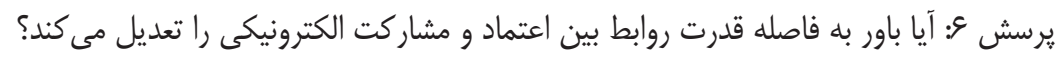

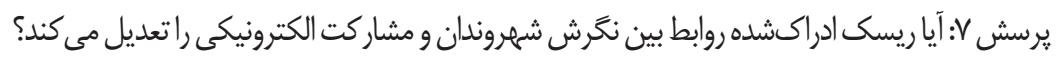

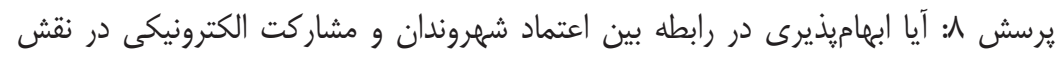

ميانجى ظاهر مى شود؟ يرسش ج: آيا نگرش كار كنان در رابطه بين اعتماد شهروندان و مشاركت الكترونيكى در نقش ميانجى ظاهر مى شود؟

\section{روش اشناسى ثئوهش}

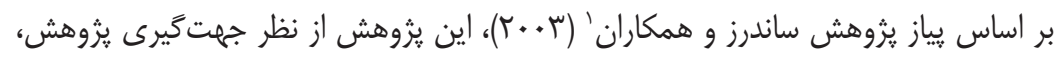

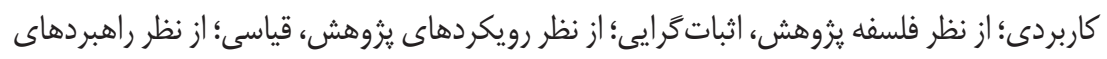

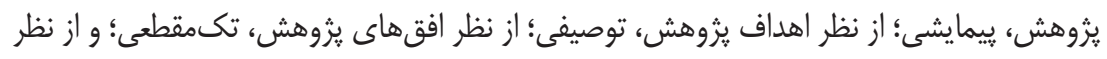

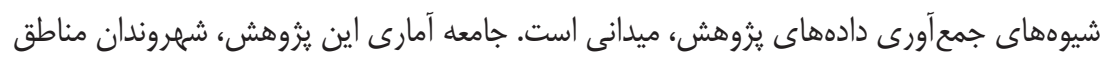

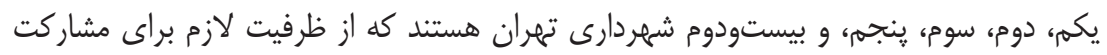

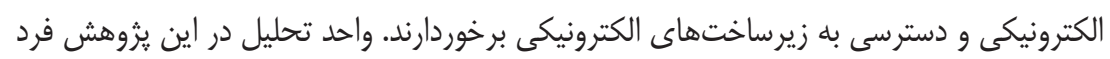

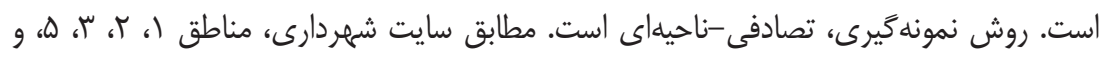

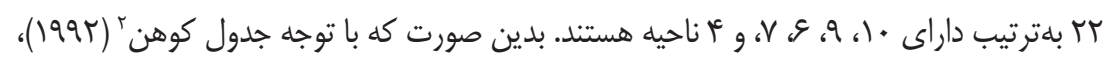

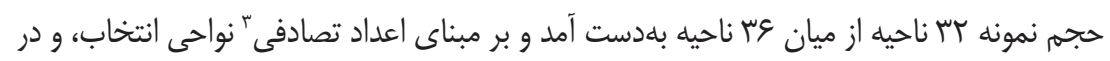

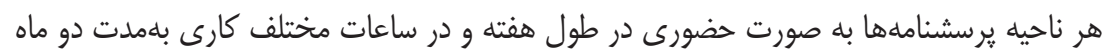

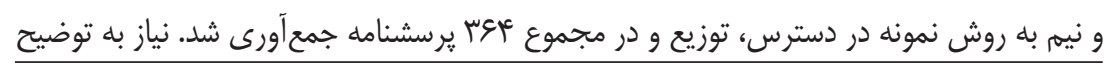

1. Saunders et al.

2. Cohen

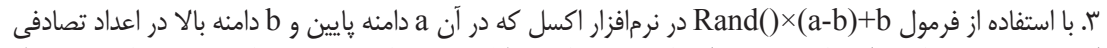

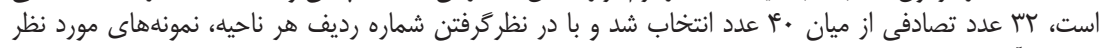


است كه يرسشنامهها در اختيار افرادى قرار مى گرفت كه حاضر به تكميل يرسشنامه در محل بودند. بنابراين، نرخ بازگشت يرسشنامهها ...1 درصد بود و تمامى يرسشنامههاى تكميلشده، معتبر و

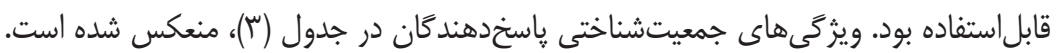

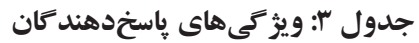

\begin{tabular}{|c|c|c|c|c|c|c|c|c|c|c|c|c|c|}
\hline & \multicolumn{2}{|l|}{ تحصيلات } & \multicolumn{2}{|c|}{ ماهيت شغل } & \multicolumn{4}{|c|}{ قوميت فرهنكى } & \multicolumn{2}{|c|}{ جنسيت } & \multicolumn{2}{|r|}{ سن } & \\
\hline$\xi$ & 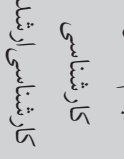 & $\begin{array}{l}6: \\
6 \\
6 . \\
z \\
z \\
6\end{array}$ & 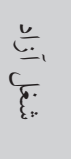 & 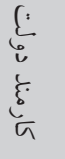 & $\bar{\varepsilon}$ & $\frac{\xi}{\xi}$. & $\bar{n}_{n}$ & $\underbrace{\mathfrak{n}}_{\underline{G}}$ & $\xi^{\prime}$ & C: & 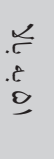 & 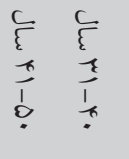 & 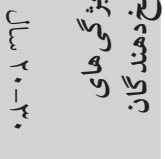 \\
\hline 10 & $|r \Delta| Q \mid$ & $v^{r}$ & IVG & $1 M$ & Yr & $r m q$ & r & VA & THE & 14. & 99 & Ve ler & Vراوانى \\
\hline r & MY KY & $r$. & $\varphi \wedge$ & Or & V & 94 & 4 & TI & $91 / 0$ & rN/D & 19 & $r \cdot r \cdot$ & درصد (\%) إ \\
\hline
\end{tabular}

\section{سنجش متغير هاى ثخوهش}

Bندين ابزار براى سنجش مشاركت الكترونيكى وجود دارد Beaumaster, 2007; Krishnan et al., 2017; Vidiasova et al., 2016 متمر كز شويه كه از روايى بالايى برخوردار هستند. معروفترين ابزار سنجش مشاركت الكترونيكى، مقياس (2013) UNDESA است كه داراى سه زيرمقياس تصميمگيرى الكترونيكى، مشورت الكترونيكى، و تامين اطلاعات الكترونيكى است: تصميه گيرى الكترونيكى: درگير شدن مستقيم شهروندان در فرايندهاى تصميهَيرى؛ مشورت الكترونيكى: سازماندهى برخط مشاورههاى عمومى؛ و تامين اطلاعات الكترونيكى: ارائه اطلاعات از راه اينترنت. تعريف عملياتى ديگر متغيرهاى يزوهش به شرح زير است: اعتماد': نشاندهنده تمايل شهروندان براى دركير شدن در مشاركت الكترونيكى بر مرير مبناى باورهاى آنان در مورد سلامت، خيرخواهى، و شايستخى سازمانهاى عمومى است

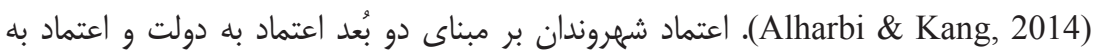
اينترنت سنجشيذير است (Bélanger \& Carter, 2008). 
نخرش': نشاندهنده احساسهاى مثبت يا منفى است كه شخص نسبت به رفتار معينى دارد

(Wu \& Chen, 2015). در حوزه مشاركت الكترونيكى، نغرش به معناى احساس مثبت يا منفى

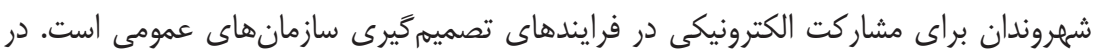

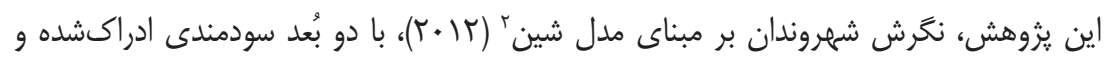

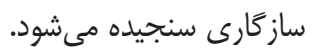
ريسك ادراكشده": ريسك، نشاندهنده وجود نبود قطعيت درباره نتيجه اقدامى است كه احتمال وقوع آسيب فيزيكى يا خسارتهاى ديكر را با به دنبال دارد.

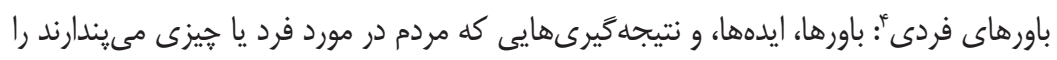
نشان مى دهند كه اين موضوع، حسى را به يك فرد منتقل مى كند (Schermerhorn et al., 2002).

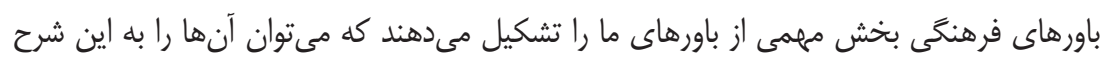

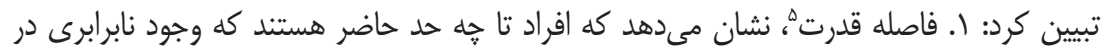

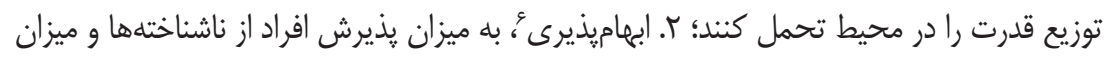

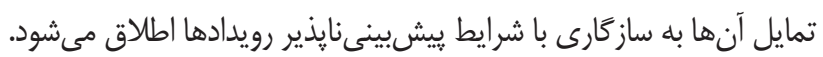

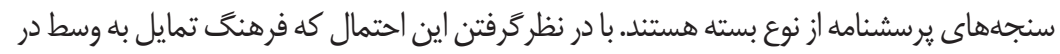

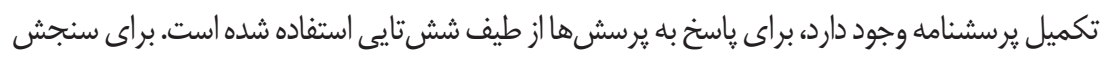

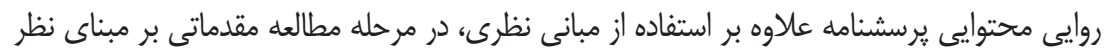

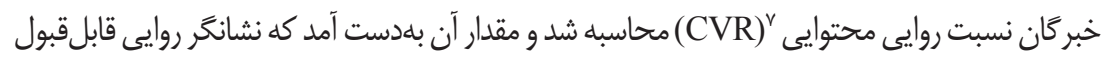

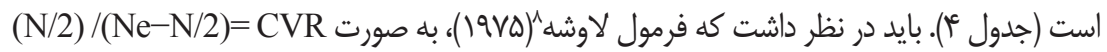

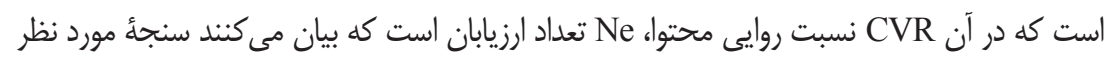

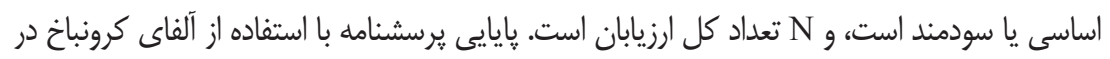

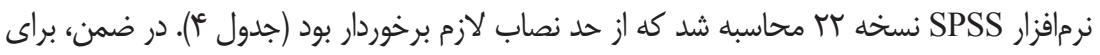

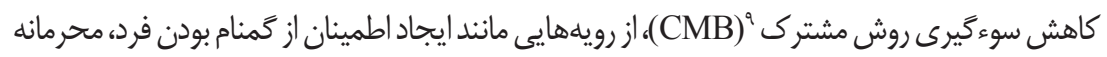

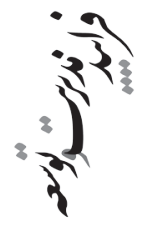

1. Attitude

2. Shin

3. Perceived Risk

4. Individual Beliefs

5. Power Distance

6. Uncertainty Acceptance

7. Content Validity Ratio (CVR)

8. Lawshe

9. Common Method Bias (CMB) 
بودن دادهها، و تخصيص تصادفى اقلام مقياس استفاده شد. به علاوه، براى كشف احتمالى سوءگيرى روش مشترك، در تحليل مدل PLS از عامل روش مكنون' (متغير نشانخر) استفاده شده است.

جدول †: ارزيابى روايع و يايايى ثرسشنامه

\begin{tabular}{|c|c|c|c|c|}
\hline كرونباخ & محتوايى (CVR) موايى & 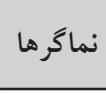 & ابعاد / مولفهها & متغير هاى بثروهش \\
\hline$\cdot / \mathrm{A}$ & $\cdot / \mathrm{V} 4$ & r & تامين اطلاعات & مشاركت الكترونيكى \\
\hline$\cdot / \mathrm{q}$ & .19 & r & تصميم گيرى & \\
\hline$\cdot / 94$ & $\cdot / 0$ & 9 & 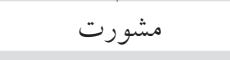 & \\
\hline.$/ 94$ & $.19 \mathrm{~V}$ & $v$ & اعتماد به شهردارى & اعتماد شهروندان \\
\hline$\cdot / 19$ & $\cdot / \mathrm{NI}$ & 0 & اعتماد به اينترنت & \\
\hline$\cdot /\left.\wedge\right|^{4}$ & $\cdot / \mathrm{OV}$ & $\wedge$ & سودمندى ادراكشده & كرايش شهروندان به مشاركت الكترونيكى \\
\hline$\cdot / \wedge \Delta$ & $\cdot / V 9$ & 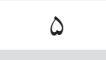 & ساز كارى & \\
\hline$\cdot / V Q$ & $\cdot / V Q$ & r & - & باور به تعديل فاصله قدرت \\
\hline .194 & $\cdot 194$ & 0 & - & ابهاميذيرى \\
\hline$\cdot / \wedge 9$ & $\cdot / V Q$ & r & --- & ريسك ادراكشده \\
\hline
\end{tabular}

\section{يافتهاى يزووهش}

آمارهاى توصيفى ابعاد مشاركت الكترونيكى (تامين اطلاعات، تصميمگيرى، و مشورت)

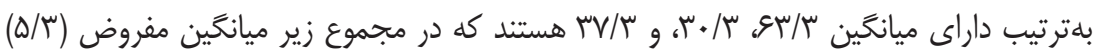

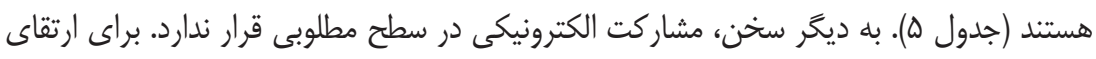

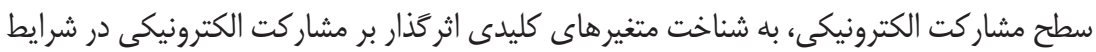
اقتصادى، سياسى، و اجتماعى تهران نياز است.

جدول ه: نتايج مربوط به سنجش مشار كت الكترونيكى

\begin{tabular}{|c|c|c|c|c|c|c|}
\hline \multicolumn{2}{|c|}{ فاصله اطمينان ه৭\% } & \multirow{2}{*}{ ميانخين } & \multirow{2}{*}{ سطح معنادارى } & \multirow{2}{*}{ درجه آزادى } & \multirow{2}{*}{ t } & \multirow{2}{*}{ ابعاد مشار كت الكترونيكى } \\
\hline كرانه بالا & كرانه يايين & & & & & \\
\hline.$/ .191$ & - /TOYY & r/gr &.$/$ rQ & rat & T/TYV & دسترسى به اطلاعات \\
\hline$-\cdot$ MYQA & $-\cdot / \cdot 0 \cdot r$ & $r / \mu$. & 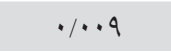 & rat & $-Y / G T Q$ & تصميم گيرى \\
\hline$-\cdot / Y 90 \%$ &.$/$ TYG & $r / \mu V$ & .1 .91 & 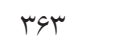 & $-1 / 90 \mathrm{~V}$ & مشورت \\
\hline
\end{tabular}

1. Latent Method Factor 
همانطور كه در جدول (ه) ديده مىشود، سطح معنادارى متغيرهاى دسترسى به اطلاعات

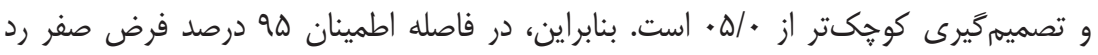

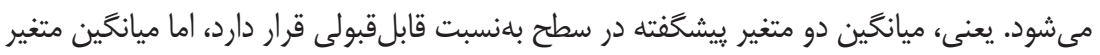
مشورت با توجه به سطح معنادارى مشاهدهشده، در سطح قابلقبولى نيست. با توجه به اين كها

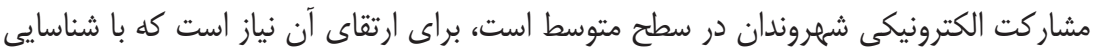
متغيرهاى كليدى اثرگذار در قالب تدوين مدل ساختارى اقدام شود. دو رويكرد در تخمين روابط در يك مدل معادله ساختارى وجود دارد. يكى از آنها رويكرد مبتنى بر كوواريانس (CB-SEM)

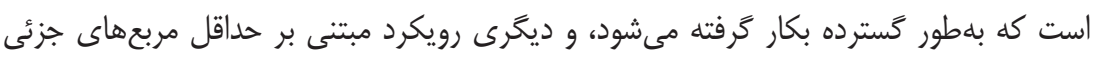

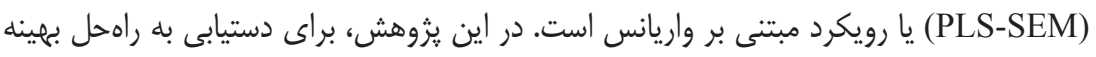

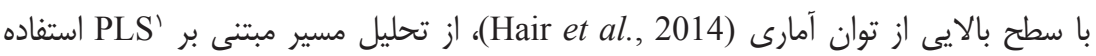

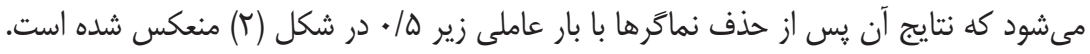
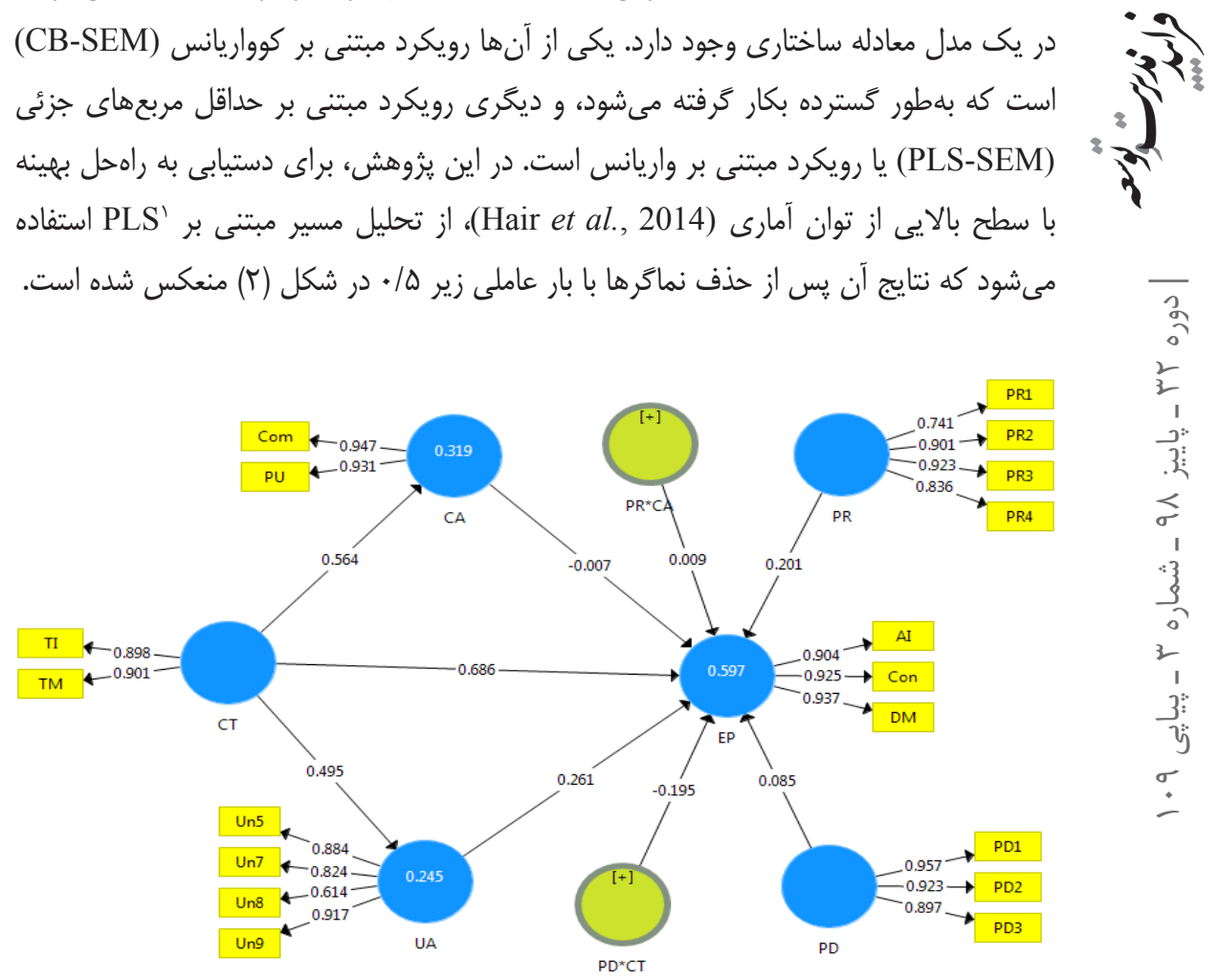

شكل r: مدل معادلههاى ساختارى مشار كت الكترونيكى شهروندان با ضرايب مسير

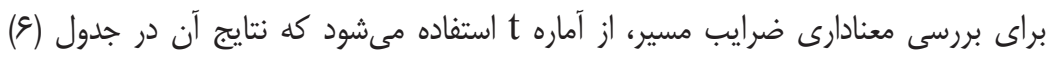

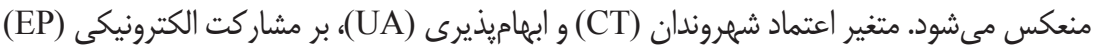


آنان اثركذار است، اما نكَرش شهروندان (CA) اثركذار نيست. به عبارت ديخر، مقادير t بزر كتر از

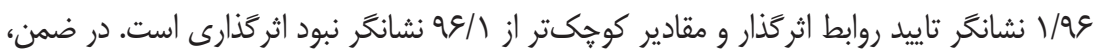
باور به فاصله قدرت (PD)، رابطه بين اعتماد شهروندان و مشاركت الكترونيكى را تعديل مى كند،

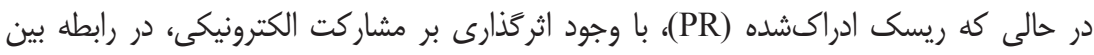

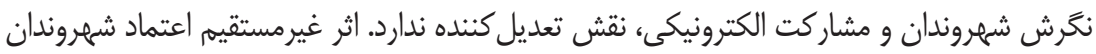

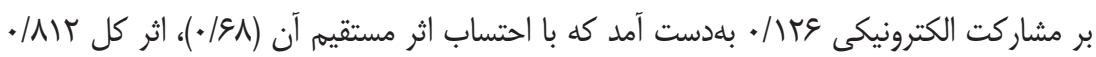

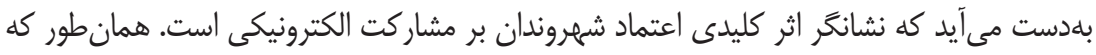

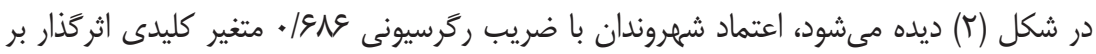
مشاركت الكترونيكى شهروندان است. در ضمن، باور به فاصله قدرت، رابطه اعتماد شهروندان و

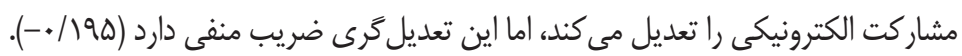

جدول و: بررسى معنادارى ضرايب مسير و آزمون روابط متغيرها

\begin{tabular}{|c|c|c|c|c|c|}
\hline نتيجه & معنادارى سطح & 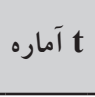 & ضريب & روابط متغيرها & نوع متغير \\
\hline تاييد & $\cdot / \cdots$ & $V / q 4 q$ & $\cdot / 9 \wedge 9$ & اعتماد شهروندان ـ مشاركت الكترونيكى & اثر كذارى اعتماد شهروندان بر \\
\hline تاييد & $\cdot / \cdots$ & $V / q 4 q$ & $.19 \wedge 4$ & اعتماد شهروندان ـ مشاركت الكترونيكى & نقش ميانجى گرى نخرش \\
\hline تاييد & $\cdot / \cdots$ & $9 / 00 \wedge$ & $\cdot 1094$ & اعتماد شهروندان ـ نخرش شهروندان & اعتماد شهروندان در رابطه بين مشاركت \\
\hline 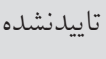 &.$/ 9 \cdot 9$ & $\cdot / 11 \wedge$ & $-\cdot / \cdot v$ & نحرش شهروندان ـ ـمشاركت الكترونيكى & الكترونيكى \\
\hline تاييد & $\cdot / \cdots$ & $V / 949$ & $\cdot 19 \wedge 9$ & اعتماد شهروندان ـ مشاركت الكترونيكى & نقش ميانجى گرى ابهاميذيرى \\
\hline تاييد & $\cdot / \cdots$ & $9 / 499$ &.$/ 490$ & اعتماد شهروندان ـ ابهاميذيرى & در روابط بين اعتماد شهروندان \\
\hline تاييد & $\cdot / \cdot 1$ & $r / r q 1$ &.$/ 491$ & ابهاميذيرى ـ ـمشاركت الكترونيكى & و ومشاركت الكترونيكى \\
\hline ت اييدنشده & $\cdot / 199$ & $1 / T 94$ & $\cdot / \cdot \wedge \Delta$ & باور به فاصله قدرت ـ مشاركت الكترونيكى & نقش تعديل خرى فاصله قدرت \\
\hline تاييد & $.1 \cdot 4$ & r/VGa & $-\cdot / 190$ & باور به فاصله قدرت × اعتماد شهروندان ـ مشاركت الكترونيكى & در ومشاركت بين الكتماد شهروندان \\
\hline تاييد & $\cdot / \cdot 11$ & T/MVG & $\cdot / r \cdot 1$ & ريسك ادراكشده ـ مشاركت الكترونيكى & نقش تعديل خرى ريسك \\
\hline ت ايايدنشده & . /Ars & $\cdot / T \cdot V$ & $\cdot 1 \cdot 9$ & ريسك ادراكشده × نخرش شهروندان ـ مشاركت الكترونيكى & نحرش شهروندان و مشاركت درو روابط بين \\
\hline
\end{tabular}


همانطور كه در جدول (9) ديده مىشود، بررسى معنادارى تاثير ميانجى متغير نكرَش

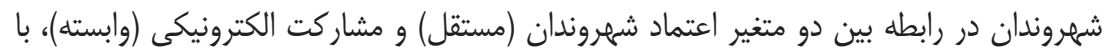

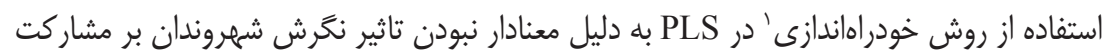

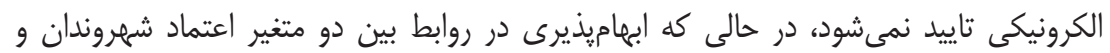

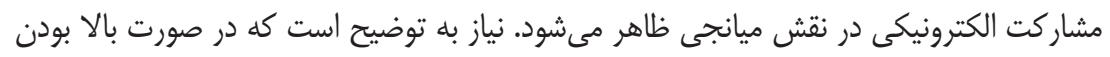

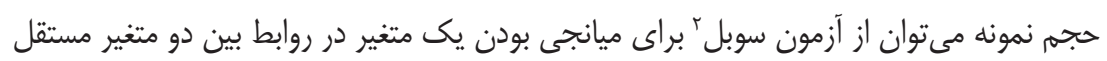

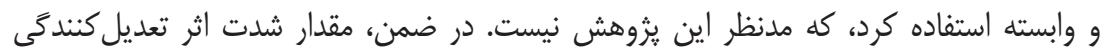

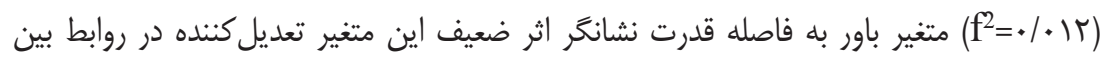

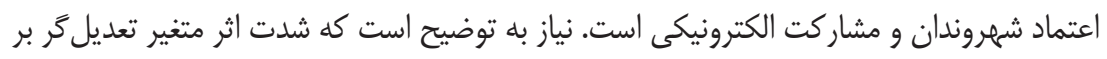

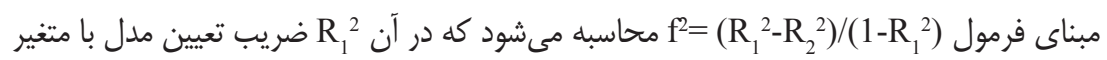

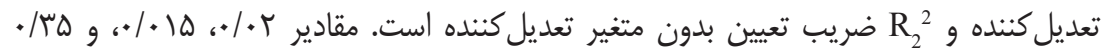
بلدترتيب اثرهاى ضعيف، متوسط، و قوى را نشان مىدهند.

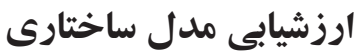

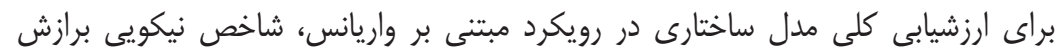

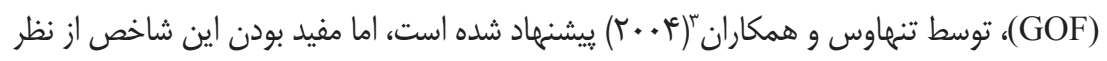

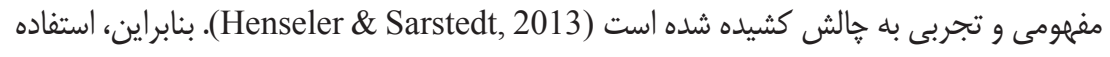

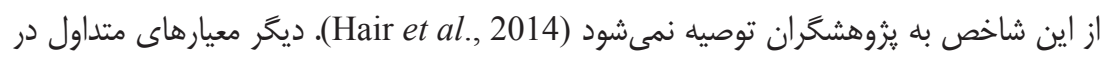
ارزشيابى مدل ساختارى عبارتاند از بايايى سازوارى داخلى (يايايى مركب)، روايى همكَرا، روايى

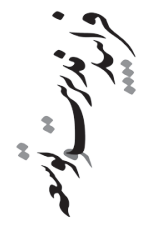

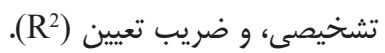

1. Bootstrapping

2. Sobel

3. Tenenhaus et al. 
جدول Y: بروسى يايايى و روايى مدل يزوهش

\begin{tabular}{|c|c|c|c|c|}
\hline روايى تشخيصى & $\begin{array}{c}\text { روايى همخرا } \\
\text { (AVE) }\end{array}$ & $\begin{array}{l}\text { يايايى مركب } \\
\text { (CR) }\end{array}$ & آلفاى كرونباخ & متغير مكنون \\
\hline بلى بلى & •/ANT & $\cdot / 9 \mathrm{TV}$ & $\cdot / \Lambda 9 V$ & نخرش شهروندان (CA) \\
\hline بلى الى & $\cdot / 1 \cdot 9$ & - $/ 194$ & - Var & اعتماد شهروندان (CT) \\
\hline 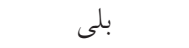 & $\cdot / \wedge \Delta \cdot$ & $\cdot / 940$ &.$/ 914$ & مشاركت الكترونيكى (EP) \\
\hline بلى بلى & $\cdot / \Lambda \Delta \wedge$ & $\cdot / 94 \wedge$ &.$/ 91 \mathrm{~V}$ & باور به فاصله قدرت (PD) \\
\hline 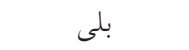 & $\cdot$ VYA &.$/ 91{ }^{\mathrm{C}}$ & ./AVG & ريسك ادراكشده (PR) \\
\hline بلى بلى & $.19 \mathrm{~V}$. & $\cdot / \mathrm{AM}$ & - /ATq & ابهاميذيرى (UA) \\
\hline
\end{tabular}

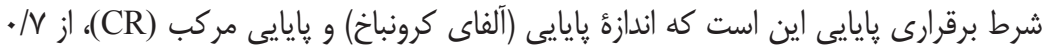

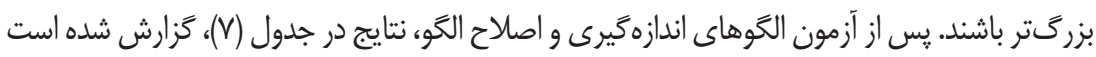

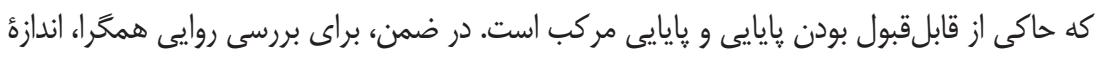
متوسط واريانس استخراجشده (AVE)، بايد از ه/ • بزركَتر باشد (Fornell \& Larcker, 1981).

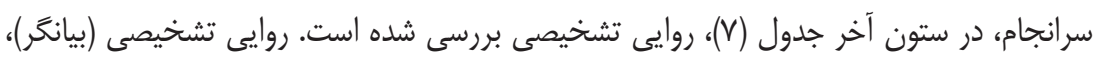

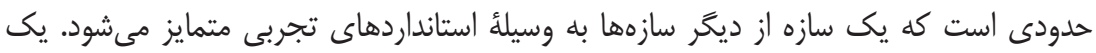

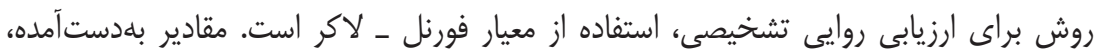
روايى واگر ایى سازهها را تاييد مى كند.

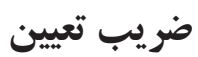

ضريب تعيين (R2)، بيانكر ميزان واريانس تبيينشده در متغير وابسته برحسب متغيرهاى

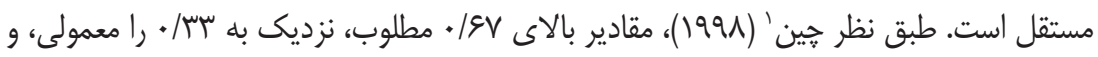

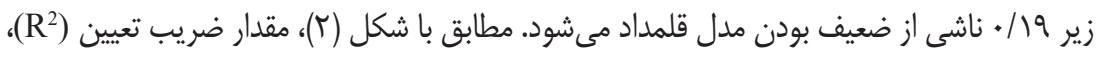

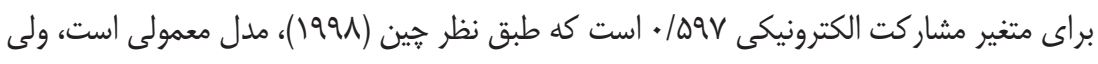

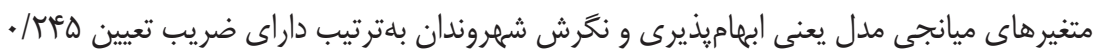
و وآ/ • هستند كه در سطح معمولى متمايل به ضعيف هستند.

1. Chin 


\section{بحث و نتيجه كيرى}

امروزه با كسترش فناورىهاى اطلاعاتى و ارتباطى در عصر اطلاعات، كذر از سازوكارهاى

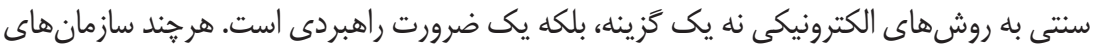

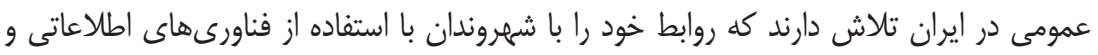

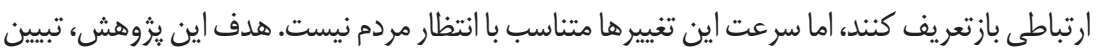

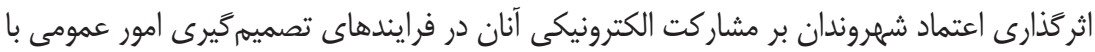

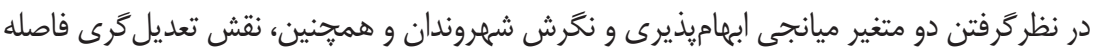

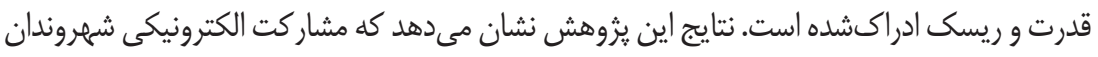

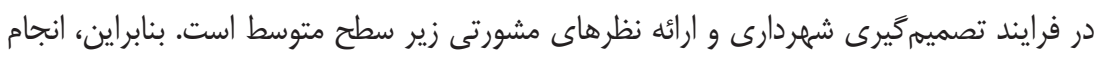

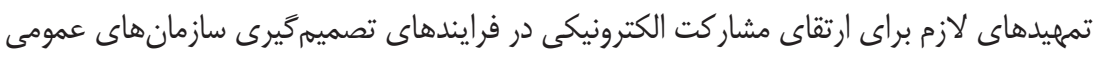

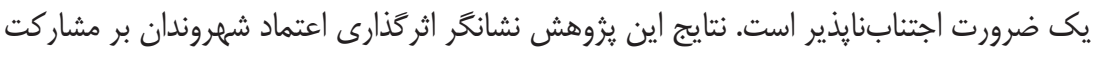

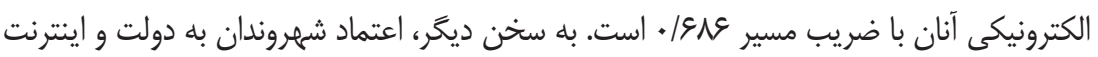

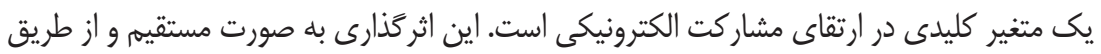
متغير ميانجى ابهاميذيرى صورت مى گيرد. به علاوه، اين يزوهش نشان مى دهد كه رابطه بين اعتماد

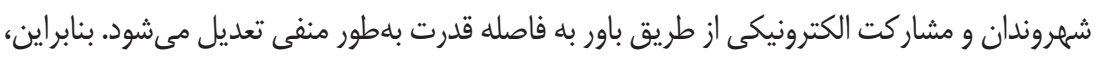

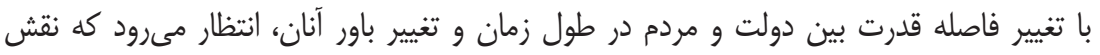

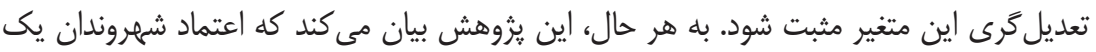

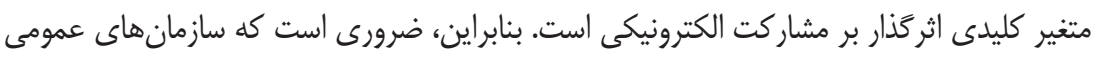

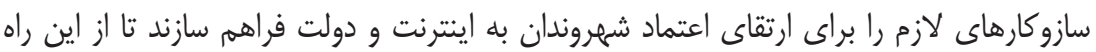

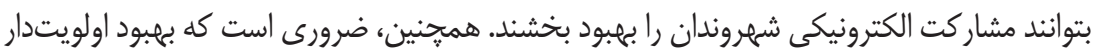

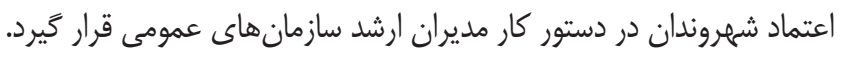

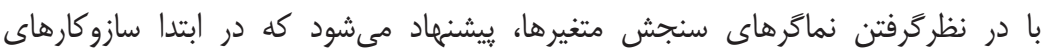

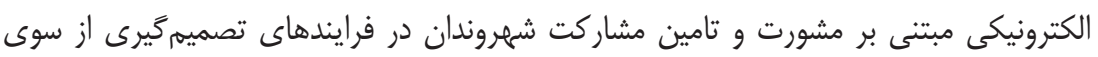

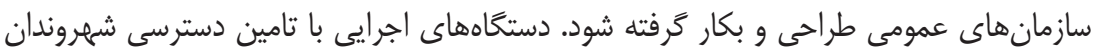

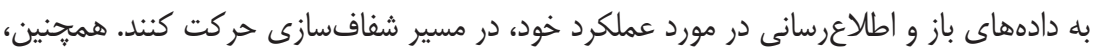

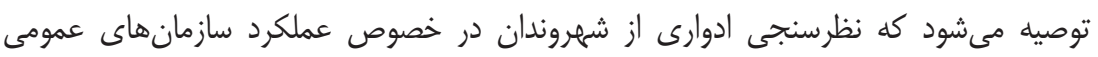

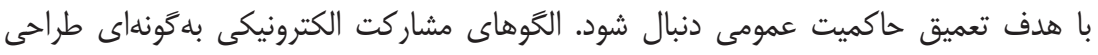

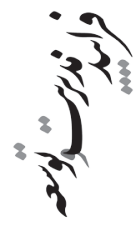


شوند كه ريسك ادراكشده پإيينى از نظر ايمن بودن اطلاعات راهبردى، بييخيرى ارائه خدمات

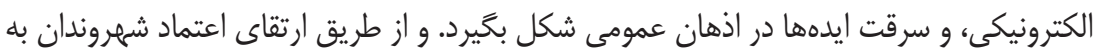

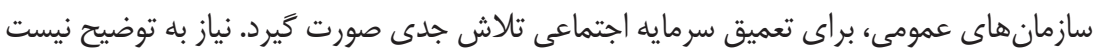

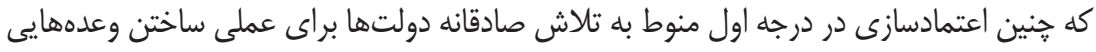
است كه در برنامههاى انتخاباتى خود مطرح مي كنند.

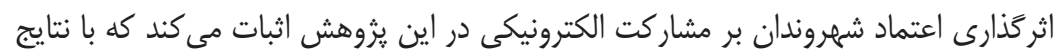

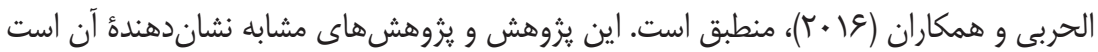
كه شهروندان با اعتماد بالا به دولت و سازمان هاى عمومى و اينترنت، تمايل بالايى براى مشاركت

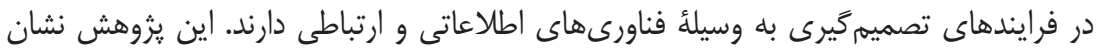
مىدهد كه ابهاميذيرى در رابطه بين اعتماد شهروندان و مشاركت الكترونيكى در نقش ميانجى

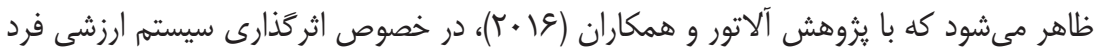

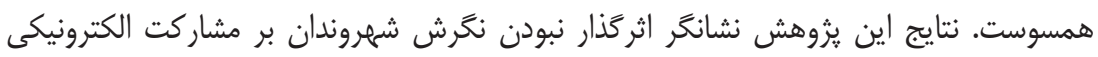

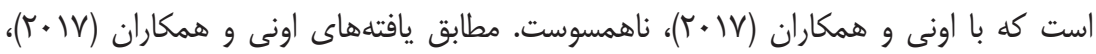

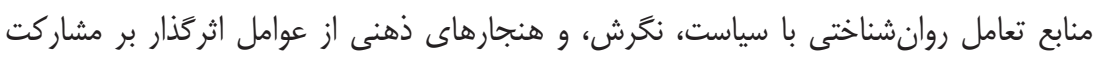

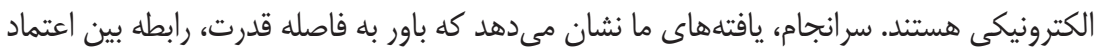

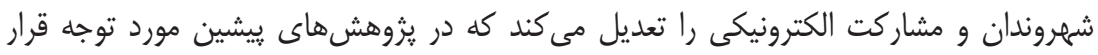

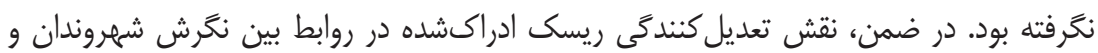

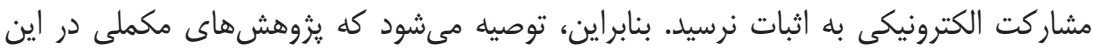

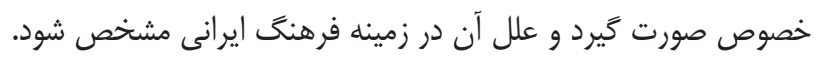

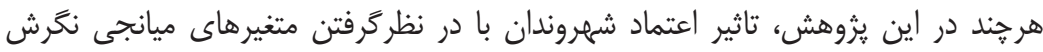
شهروندان و ابهاميذيرى آنان در سطح فردى مدلسازى شد، و ضريب تعيين بهدستأمده (D9V/•)، نشانكر مطلوبيت نسبى مدل در ييشيينى مشاركت الكترونيكى است، اما براى دستيابى به مدل

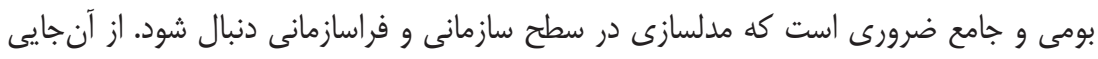
كه يافتهاى اين يزوهش ناظر بر شهردارى تهران، به عنوان يك سازمان عمومى در ايران است،

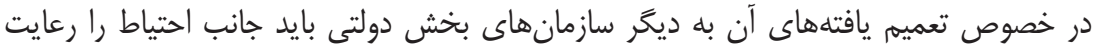

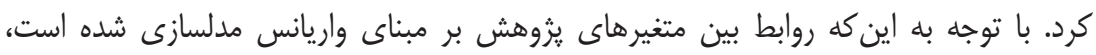
نبايد محدوديت اين روش را در مقايسه با مدلسازى ساختارى مبتنى بر كوواريانس، و همجنين سوءگيرى احتمالى روش مشترى ناديده كرفت. 


\section{منابع}

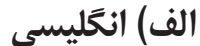

Alathur, S., Ilavarasan, P. V., \& Gupta, M. (2016). Determinants of E-Participation in the Citizens and the Government Initiatives: Insights from India. SocioEconomic Planning Sciences, 55(1), 25-35.

Albrecht, S., Kohlrausch, N., Kubicek, H., Lippa, B., Märker, O., Trénel, M., Vorwerk, V., Westholm, H.H., Wiedwald, C. (2008). E-ParticipationElectronic Participation of Citizens and the Business Community in EGovernment. Study on Behalf of the Federal Ministry of the Interior (Germany), Division IT, 1(1).

Al-Dalou, R., \& Abu-Shanab, E. (2013). E-Participation Levels and Technologies. Paper Presented at the 6th International Conference on Information Technology (ICIT 2013).

Alharbi, A., \& Kang, K. (2014). E-Participation Service in Saudi Arabian E-Government Websites: The Influencing Factors from Citizens'Perspective. Paper Presented at the European Conference on E-Government.

Alharbi, A., Kang, K., \& Hawryszkiewycz, I. (2016). The Influence of Trust and Subjective Norms on Citizens Intentions to Engage in E-Participation on E-Government Websites, Australasian Conference on Information Systems, Adelaide.

Andrews, L., \& Boyle, M. V. (2008). Consumers' Accounts of Perceived Risk Online and the Influence of Communication Sources. Qualitative Market Research: An International Journal, 11(1), 59-75.

Beaumaster, S. (2007). E-Participation. Models Modern Public Information Technology Systems: Issues and Challenges (127-142): IGI Global.

Bélanger, F., \& Carter, L. (2008). Trust and Risk in E-Government Adoption. The Journal of Strategic Information Systems, 17(2), 165-176.

Chin, W. W. (1998). The Partial Least Squares Approach to Structural Equation Modeling. Modern Methods for Business Research, 295(2), 295-336.

Cohen, J. (1992). A Power Primer. Psychological Bulletin, 112(1), 155-159.

Coleman, S. (2005). The Lonely Citizen: Indirect Representation in an Age of Networks. Political Communication, 22(2), 197-214.

Damurski, L. (2012). E-Participation in Urban Planning: Online Tools for Citizen Engagement in Poland and in Germany. International Journal of E-Planning Research (IJEPR), 1(3), 40-67.

Denny, K., \& Doyle, O. (2008). Political Interest, Cognitive Ability and Personality: Determinants of Voter Turnout in Britain. British Journal of 
Political Science, 38(2), 291-310.

Edelmann, N., \& Cruickshank, P. (2012). Introducing Psychological Factors into

E-Participation Research. E-Governance and Civic Engagement: Factors and Determinants of E-Democracy (338-361): IGI Global.

Fornell, C., \& Larcker, D. F. (1981). Evaluating Structural Equation Models with Unobservable Variables and Measurement Error. Journal of Marketing Research, 18(1), 39-50.

Francoli, M. (2008). E-Participation and Canadian Parliamentarians. Electronic Government: Concepts, Methodologies, Tools, and Applications (pp. 1547-1554): IGI Global.

Gunter, B. (2006). Advances in E-Democracy: Overview. Aslib Proceedings. 58(5), 361-70.

Hair, J. F., Hult, G. T. M., Ringle, C., \& Sarstedt, M. (2014). A Primer on Partial Least Squares Structural Equation Modeling (PLS-SEM): Los Angeles: SAGE.

Hansson, K., \& Fürst, J. G. (2013). Methodology for Sustainable E-Participation: Redistribution, Representation and Recognition. Paper Presented at the MeTTeG 2013 7th International Conference on Methodologies, Technologies and Tools Enabling E-Government.

Henseler, J., \& Sarstedt, M. (2013). Goodness-of-Fit Indices for Partial Least Squares Path Modeling. Computational Statistics, 28(2), 565-580.

Heron, J. (1996). Co-Operative Inquiry: Research into the Human Condition: Sage.

Holgersson, J., \& Karlsson, F. (2014). Public E-Service Development: Understanding Citizens' Conditions for Participation. Government Information Quarterly, 31(3), 396-410.

Irvin, R. A., \& Stansbury, J. (2004). Citizen Participation in Decision Making: Is it Worth the Effort? Public Administration Review, 64(1), 55-65.

Islam, M. S. (2008). Towards a Sustainable E-Participation Implementation Model. European Journal of E-Practice, 5(10), 1-12.

Jho, W., \& Song, K. J. (2015). Institutional and Technological Determinants of Civil E-Participation: Solo or Duet? Government Information Quarterly, 32(4), 488-495.

Krishnan, S., Teo, T. S., \& Lymm, J. (2017). Determinants of Electronic Participation and Electronic Government Maturity: Insights from Cross-Country Data. International Journal of Information Management, 37(4), 297-312.

Lawshe, C. H. (1975). A Quantitative Approach to Content Validity 1. Personnel Psychology, 28(4), 563-575.

Lee, A., \& Levy, Y. (2014). The Effect of Information Quality on Trust in E-Government Systems' Transformation. Transforming Government: 
People, Process and Policy, 8(1), 76-100.

Lee, J., \& Kim, S. (2012). E-Participation in the Era of Web 2.0: Factors Affecting Citizens' Active E-Participation in Local Governance. Paper Presented at the Proceedings of the 6th International Conference on Theory and Practice of Electronic Governance.

Nam, T. (2014). Determining the Type of E-Government Use. Government Information Quarterly, 31(2), 211-220.

Nchise, A., Ngwa, O., \& Mbarika, V. (2011). Toward a Sustainable E-Participation Model in Sub Saharan Africa. Paper Presented at the Conference for E-Democracy and Open Government.

Oni, A. A., Oni, S., Mbarika, V., \& Ayo, C. K. (2017). Empirical Study of User Acceptance of Online Political Participation: Integrating Civic Voluntarism Model and Theory of Reasoned Action. Government Information Quarterly, 34(2), 317-328.

Purwanto, E. (2018). Moderation Effects of Power Distance on the Relationship Between Job Characteristics, Leadership Empowerment, Employee Participation and Job Satisfaction: A Conceptual Framework. Academy of Strategic Management Journal, 17(1), 1-9.

Robert, L. P., \& Dennis, A. R. (2005). Paradox of Richness: A Cognitive Model of Media Choice. IEEE Transactions on Professional Communication, 48(1), $10-21$.

Sæbø, Ø., Flak, L. S., \& Sein, M. K. (2011). Understanding the Dynamics in E-Participation Initiatives: Looking through the Genre and Stakeholder Lenses. Government Information Quarterly, 28(3), 416-425.

Sæbø, Ø., Rose, J., \& Flak, L. S. (2008). The Shape of E-Participation: Characterizing an Emerging Research Area. Government Information Quarterly, 25(3), 400-428.

Sanford, C., \& Rose, J. (2008). Designing the E-Participation Artefact. International Journal of Electronic Business, 6(6), 572-589.

Saunders, M., Lewis, P., \& Thornhill, A. (2003). Research Methods for Business Students Instructors Manual: FT Prentice Hall.

Scherer, S., \& Wimmer, M. A. (2014). Conceptualising Trust in E-Participation Contexts. Paper Presented at the International Conference on Electronic Participation.

Schermerhorn Jr, J., Hunt, J., \& Osborn, R. (2002). Organizational Behavior. United States/New York: John Wiley\&Sons: Inc.

Shin, E. (2012). Attitudinal Determinants of E-Government Technology Use among US Local Public Managers. Paper Presented at the 2012 45th Hawaii International Conference on System Sciences. 
Stieglitz, S., \& Brockmann, T. (2013). The Impact of Smartphones on EParticipation. Paper Presented at the 2013 46th Hawaii International Conference on System Sciences.

Susha, I., \& Grönlund, Å. (2012). E-Participation Research: Systematizing the Field. Government Information Quarterly, 29(3), 373-382.

Tenenhaus, M., Amato, S., \& Esposito Vinzi, V. (2004). A Global Goodnessof-Fit Index for PLS Structural Equation Modelling. Paper Presented at the Proceedings of the XLII SIS Scientific Meeting.

Tundjungsari, V., Istiyanto, J. E., Winarko, E., \& Wardoyo, R. (2011). E-Participation Modeling and Developing with Trust for Decision Making Supplement Purpose.

UNDESA (2013). DPADM Concept Paper 'Developing Capacity for Participatory Governance through E-Participation. Report from the Working Group for EParticipation, UN Department of Economic and Social Affairs, 1-13.

Vidiasova, L., Kachurina, P., Ivanov, S., \& Smith, G. (2016). E-Participation Tools in Science and Business Sphere Implementation: The Case of XPIR-Platform for Participation in Education Policy. Procedia Computer Science, 101(1), 398-406.

Vogt, S., Förster, B., \& Kabst, R. (2014). Social Media and E-Participation: Challenges of Social Media for Managing Public Projects. International Journal of Public Administration in the Digital Age (IJPADA), 1(3), 85-105.

Williams, C. B., Gulati, G. J. J., \& Yates, D. J. (2013). Predictors of On-line Services and E-Participation: A Cross-National Comparison. Paper Presented at the Proceedings of the 14th Annual International Conference on Digital Government Research.

Wimmer, M. A., Scherer, S., \& Appel, M. (2015). The Role of Trust in EParticipation: Predictors, Consequences, and Design. Tambouris, E.; Scholl, HJ; Janssen, M.; Wimmer, MA, 3-10.

Wu, L., \& Chen, J.-L. (2005). An Extension of Trust and TAM Model with TPB in the Initial Adoption of On-line Tax: An Empirical Study. International Journal of Human-Computer Studies, 62(6), 784-808.

Zheng, Y. (2017). Explaining Citizens' E-Participation Usage: Functionality of E-Participation Applications. Administration \& Society, 49(3), 423-442.

Zheng, Y., Schachter, H. L., \& Holzer, M. (2014). The Impact of Government form on E-Participation: A Study of New Jersey Municipalities. Government Information Quarterly, 31(4), 653-659. 


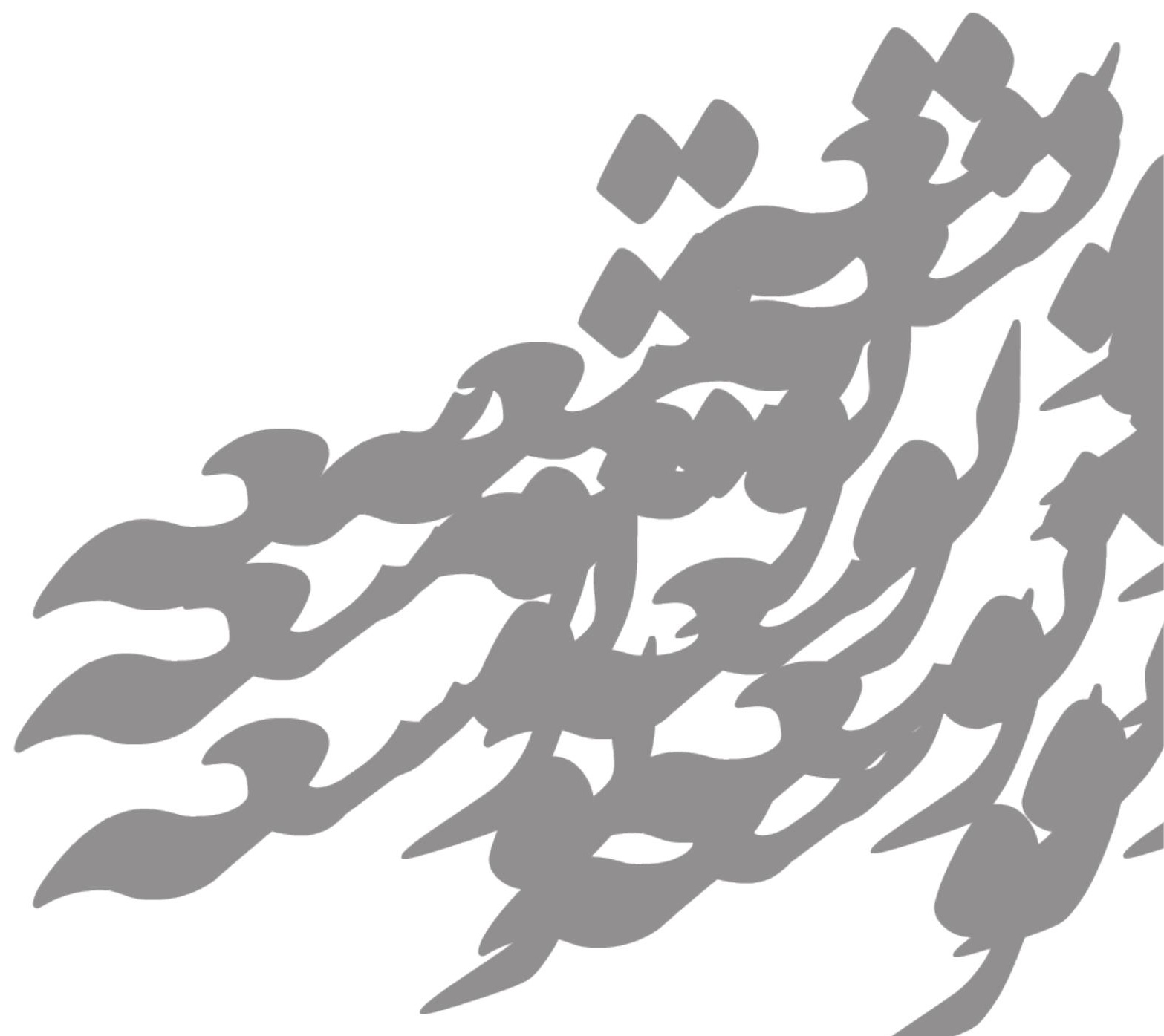

